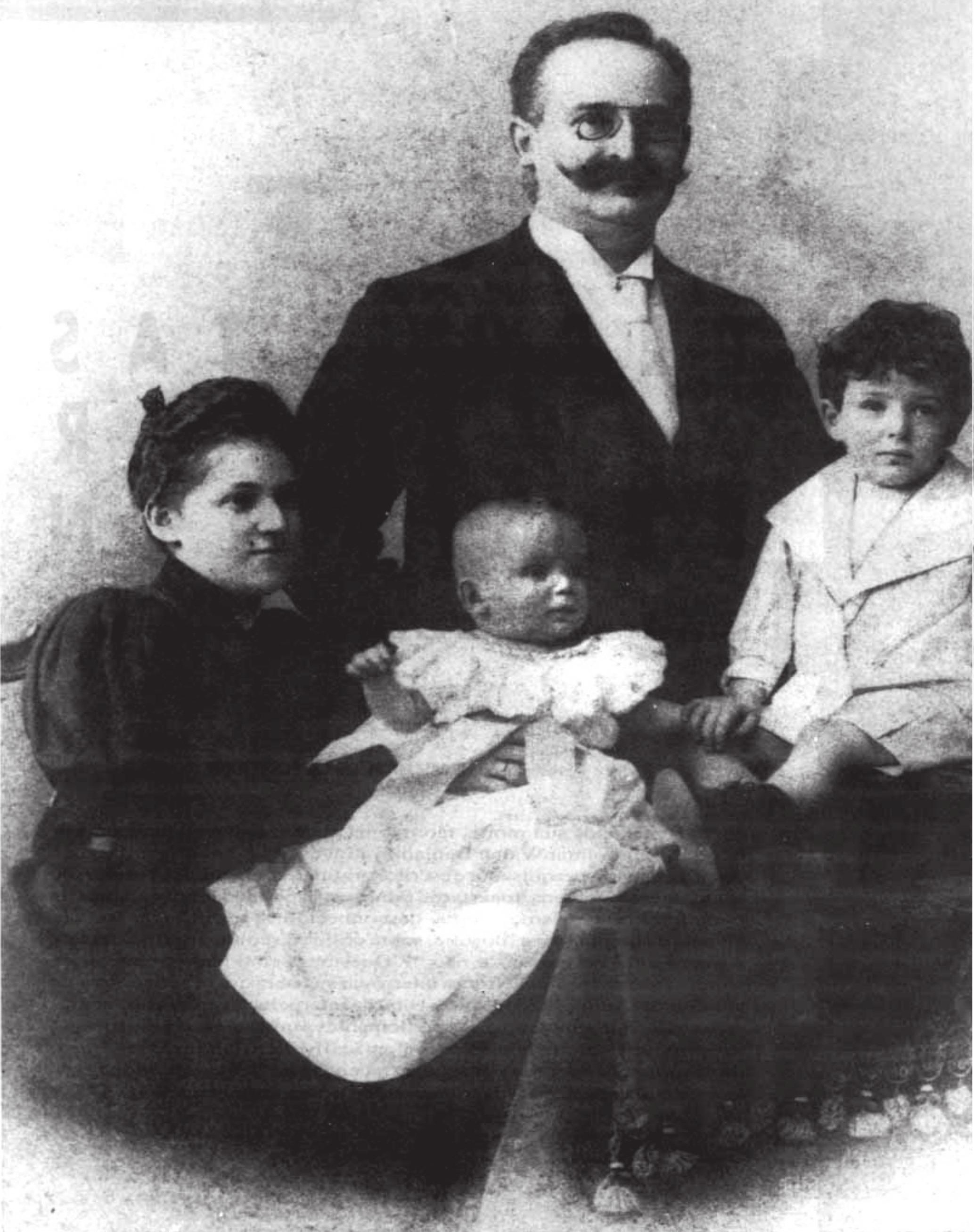




\section{Por que \\ os herdeiros \\ de Walter \\ Benjamin \\ ficaram \\ ricos com \\ o espolio?}

FILOSOFIA DA HISTORIA EM WALTER BENJAMIN

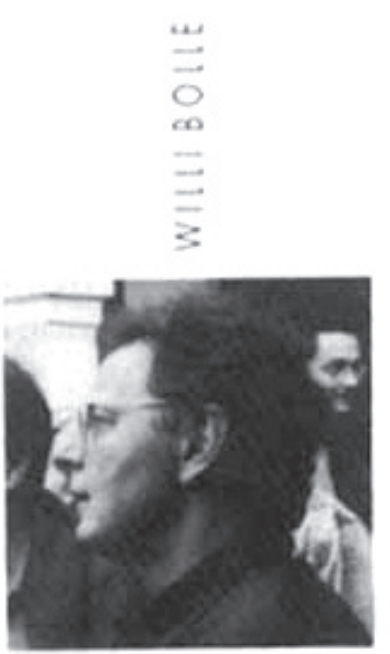

KLAUS GARBER
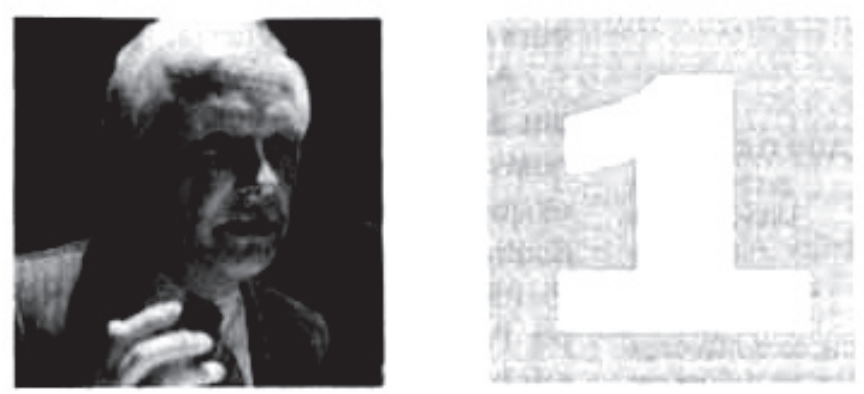


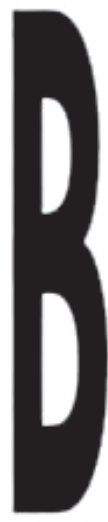

enjamin gostava de acrescentar um prefácio aos trabalhos que havia Icvado a bom termo. Mesmo que não chamasse scmpre essas introduçöes de prefácios, clas têm essa funçăo. O mais famoso exemplo disso é, provavelmente, o intróito ao ensaio sobre as Afinidades Eletivas. Na sua última versāo, a Infância Berlinense por Volta de 1900 também recebeu um prefácio, que conhecemos há pouco menos de dez anos. Permitam-me ler uma citaçāo de Walter Benjamin, para que, nestes dias de recordaçáo, possa ser ouvida aqui a voz contida e sóbria do autor que se despede:

"No ano de 1932, quando eu estava no exterior, começou a ficar claro, para mim, que logo teria de me despedir por muito tempo, talvez para sempre, da cidade $\mathrm{em}$ que nasci.

Repetidas vezes, havia tido a experiência de que o processo de vacinaçāo fora salutar para minha vida interior. Também nesta situaçāo cu me ative a isso e evoquei propositalmente aquelas imagens que, no exílio, costumam despertar a saudade com maior intensidade: as imagens da infância. O sentimento da nostalgia nāo deveria, $\mathrm{cm}$ tais circunstâncias, assenhorear-se do cspírito, da mesma forma que a vacina náo se assenhoreia do corpo sadio. Tentei mantêlo dentro de certos limites através da noçāo da irrecuperabilidade, nāo biográfica c casual, mas necessária c social, do passado.

Conseqüentemente, os traços biográfi$\cos$, que se delineiam mais intensamente na continuidade do que na profundidade da experiência, passaram, durante estas tentativas, a segundo plano. Com eles, as fisionomias - as da minha familia e as de meus companheiros. Em contraposiçāo, empenhei-me $\mathrm{em}$ captar as imagens nas quais se precipita a experiência urbana de uma criança da burguesia.

Acho possivel que tais imagens tenham um destino próprio. Nẫo há, a sua espera, quaisquer formatos preexistentes, tais como os que estảo à disposiçāo desde há séculos, dentro do sentimento pela natureza, para a memória de uma infância passada no campo. Por outro lado, porém, as imagens da minha infância na cidade grande talvez scjam capazes de pré-formar $\mathrm{em}$ seu interior uma experiência histónica posterior.Pelo menos nisto, assinı espero, é perceplível até que ponto aquele, de quem aqui se fala, teve de abrir māo, mais tarde, da sensaçáo de aconchegoque the coubera na infancia" (1).

Em 1932, Benjamin cstava cm lbiza. Aos quarenta anos, ocupava-se com a redação, já começada cm Berlim, das suas lcmbranças de infância, a Crônica Berlinense. Foi o ano $\mathrm{cm}$ que, viajando de Ibiza para Nice, passando por Paris, pensou em cometer suicidioe, ao que tudo indica, só desistiu no último momento. Pouco tempo depois iniciou em Poveromo, onde passou o verāo c o outono de $1932 \mathrm{com}$ Wilhelm Speyer, a recscritura da Crônica, que iria dar na $/ n$ fäncia Berlinense, $\mathrm{c}$ a continuou no seu último invernocm Berlim, ode 1932-33, através de um elo desconhecido até há pouco, constituído de dezessete versóes em prosia rítmica, que os gloriosos editores de Frankfurt mantiveram ocultas durante décadas. Esta recscritura chegaria a um primeiro encerramentocomoassinchamado" cxemplarStefan", cujos trabalhos prévios, aoque tudo indica, foram parar nas mũos de Gretel Adorno cm 1940, como "exemplar Felicitas". O trabalho foi retomado no primeiro ano de exilio, 1933, cm Paris e lbiza e encerrado $\mathrm{em}$ abril de $1934 \mathrm{com}$ uma versảo pronta para a impressío. Na primavera de 1938 surgiu, entīo, uma versĩo totalmente revista, que trazia como introduçîio o já mencionado prefício (2).

A evocaçẩo da infáncia ocorre cara a cara com a morte, a morte individual e a morte coletiva. Quando Benjamin se despediu de Berlim, não sabia apenas que nun-

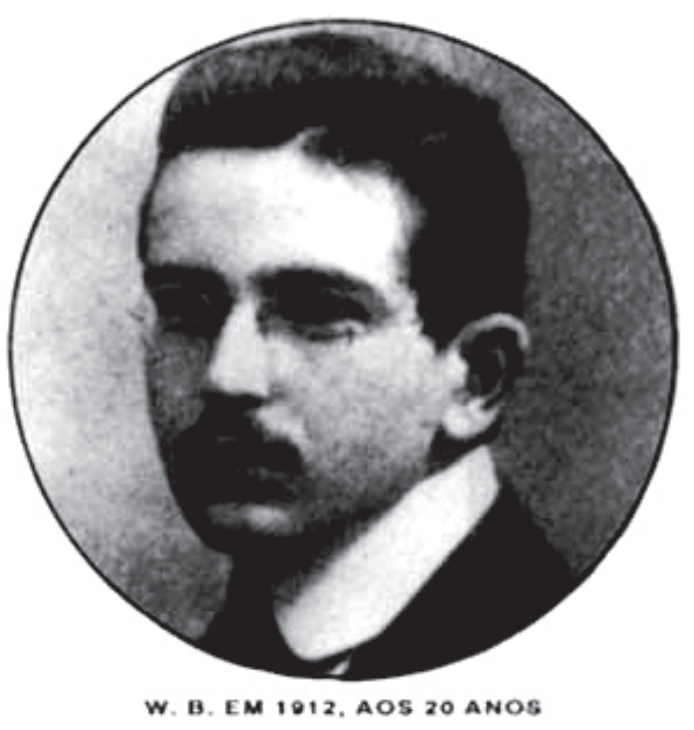


ca mais iria ver a cidade de sua infancia. Sabia também que o fascismo iria cobrir inevitavelmente a Europa com o manto da guerra e que esta teria também uma nova qualidade, a de guerra aérea que apagaria toda uma série de paisagens urbanas surgidas ao longoda história. Seja oque for que puder ser dito a respeito de suas imagens de infância berlinense, antes de mais nada, elas fixam um retrato dos tempos anteriores à destruiçâo total da cidade, um retrato da velha Alemanha, da velha Europa. Enquanto são pronunciadas estas palavras $\mathrm{em}$ solo latino-americano, em setembro de 1990, a Alemanha cindida, amputada de um quarto de seu territóriode pré-guerra, é novamente rejuntada nas mais dúbias circunstâncias, sem uma nova constituição, sem plebiscito e após um assalto monetário e uma derrubada cultural sem igual na história dos povos civilizados, isto é, um estado que foi tornado incapaz de agir é agregado ao participe dos vitoriosos da Guerra Fria. Nảo quero me delongar neste aspecto. Só quero dizer que, enquanto este processo nảo for acompanhado da memória de pelo menos très acontecimentos, a saber, do ataque contra os povos da Europa e da União Soviética, da aniquilação ou do exílio dos judeus e dos participantes do movimento operário e, por último, da destruiçảo das paisagens culturais da Europa Central e Oriental, nascidas e desenvolvidas ao longo da história $\mathbf{c}$ presentes dia a dia, como experiência que conduzia todo passo e toda reflexāo, enquanto isso nảo ocorrer, não é de se esperar um futuro de benesses para este assim chamado processo de unificação, nem para esta Alemanha, destruída tanto do lado ocidental quanto do lado oriental, não obstante todoo brilho, nem para a Europa $\mathrm{cm}$ geral - $\mathrm{co}$ trato com os autores do exilio estará envolto por profundas sombras. Os sobreviventes nảo deveriam se furtar a dizer tais coisas, em memória dos mortos.

Antes de tratar do tema que me foi proposto, interessa-me uma pergunta, que não posso responder, e que por isso quero colocar de início. Por que está reservada às imagens a capacidade de pré-formar a experiência histórica posterior? Por que a clas, $\mathrm{c}$ nảo à doutrina filosófica ou ao testemunho teológico ou ao relato pragmático ou à reportagem ou à manifestação autobiográfica, tâo próxima dos acontecimentos? Ou será que, em princípio, todos se encontram no mesmo nível enquanto arquivos ou geradores de experiência histórica? Não, acho

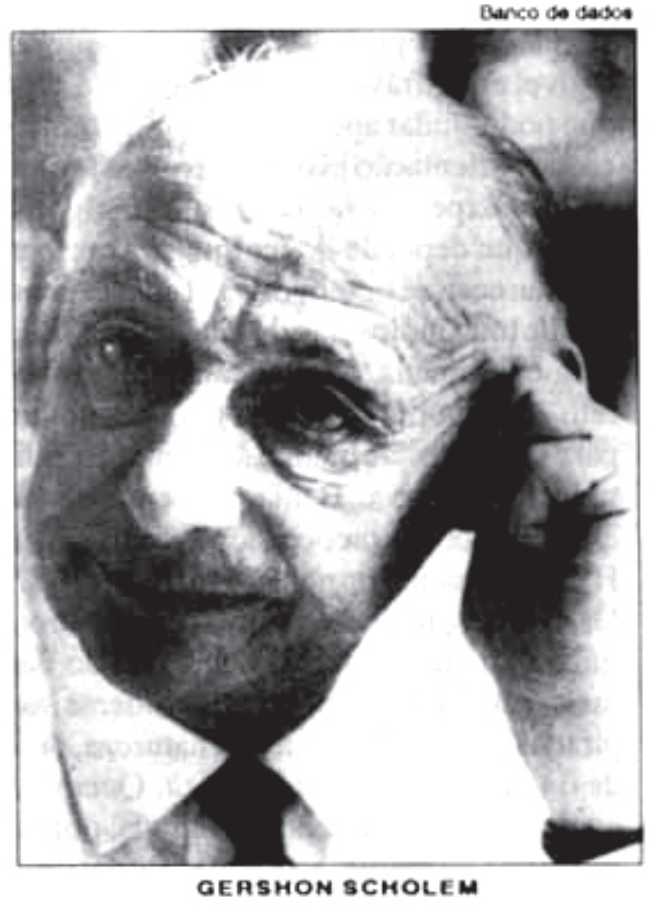

que Benjamin estava disposto $\mathrm{c}$ preparado para adjudicar um status $\mathrm{c}$ uma hicrarquia especiais às imagens $\mathrm{c}$ às obras. Durante toda sua vida, recusara-se a fixar as obras a influências, experiências, mecanismoscausais de qualquer espécic. A historia da arte, neste sentido, foi para clc, até o fím, um verdadeiro disparate e, na melhor das hipóteses, o encaixe de uma obra num campo de força histórico-social tornou-se cada vez. mais importante para cle, como o demonstra o seu Baudelaire. Tanto mais enfaticamente ele reconhecia nas obras $\mathrm{c}$ imagens uma vida histórica própria, para além das intençôes de scus autores $\mathrm{c}$ de scus primeiros comentaristas contemporâncos, vida histórica esta que tinha, $\mathrm{cm}$ princípio, uma durabilidade ilimitada. Esta sua indestrutibilidade histórica tem a ver, como nos ensina o prefácio citado e outras manifestaçôes de Benjamin, com a sua capacida. de de se independizar das vivências, sentimentos e vidas dos criadores das obras $\mathrm{c}$ imagens e de absorver e incorporar as experiências históricas transindividuais, coletivas. A chama viva da verdade casada com a bela aparência, que nada mais representa do que a chama da vida, continua a arder, como já dissera a introduçẩo ao ensaio sobre as Afinidades Eletivas "para além do grave fracasso do que foi $\mathbf{c}$ da leve cinza do vivenciado". Elas devem conter, portanto, alguma coisa que as cleva por sobre $\mathrm{e}$ as distingue do documento histórico. Elas devem abrigar em "seu interior", como diz

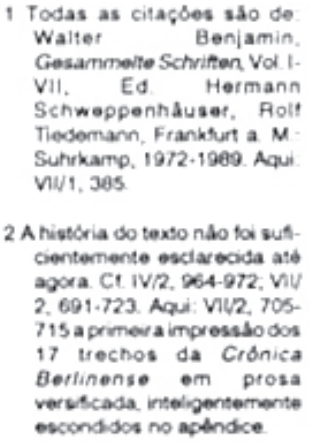

2 A histcria do texto ndo for suscientemente esciarocida ate agora Ct. IV/2, 964-972; VU $2,691.723$ Aqui VIV2, 705 715 a primen a impressbo dos 17 trechos da Crónica berlinense em prosa verchcada inteligerternerte escondidos no aptindce. 
3 Isto ó mostrado com mestria ios ensaios de Robert Minder. Ct, sobrotudo, A. M, Kultur und Lteratur in Deutschland und Frankreich, füt Essays. Franisturt a. $M$ : Insel 1962: idem: Dichter in der Coselisenan Ertarungenm

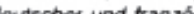
deutscher und tranzósischer Literatur, Frankfurt a. M. Insel 1966.

4 Vide: Die Unwirklichkeit der $S \quad I$ a $t$. GroBstadtdarstelfungen twischen Moderne und Postmoderne, Ed. Klaus A. Scherpe. Reinbeck bei Hamburg 1988 (rowohits onzyklopasio 471)

5 Quem foi mais longe nesta em preitada até hoje foi Bernd Witte: "Bilder der Endzeit, zu anern authentschen Text der Berliner Kindheit von Walter Benjamin", in Doutsche Vierteljahresschrift fiv? Literaturwissenschaft und Geistespeschichte 58 (1984). $570-92$.

6 GS, V/1, 573
Benjamin no prefácio, algo que se torna legível e decifrável apenas mais tarde, algo que pode ajudar apenas as geraçôes futuras em sua orientaçāo histórica, em sua formaçāo de experiência, em resumo, alguma coisa que depende do tempo para crescer, amadurecer, se desenvolver. Tais imagens, ao que tudo indica, são de vital importância para os homens. Se elas faltarem, acabarem, transportarem ideologia, há motivo para preocupação quanto à orientaçāo individual e coletiva. Benjamin sentia-se inquietadopor esta preocupação, comoJürgen Habermas salientou noseu trabalhode 1972. Os alemāes, mais do que quaisquer outros, tinham, à sua disposiçāo, um mundo das mais ricas, profundas, metafisicamente inspiradas imagens do reino da natureza, desde o tempo da Empfindsamkeit. Quem irá negar que elas marcaram profunda, porém inconscientemente a orientação social c política, e que os atores políticos, até o fascismo, as invocaram conscientemente c cmpregaram àsocultas? (3). A reformulaçāo de história em natureza, outrora arma por excelência da burguesia contra o ancien régime, era apenas mais um outro aspecto da estetizaçāo da política pelo fascismo, descoberta $e$ analisada por Benjamin, a qual ele tentou enfrentar mediante uma politização da arte. As imagens da Infância Berlinense ainda fazem parte desta linha. Deveriam ajudar os alemães a constituírem a sua experiência urbana, tão parcamente estruturada na sua tradição cultural, mas não uma experiência urbana qualquer, carente de especificidade, mas uma calcada com exatidão no "wilhelminismo" das últimas décadas anteriores ao ocaso definitivo do mundo burguês tardio (4). Seria extremamente interessante e constituiria um tema de per se tentarmos proceder em conjunto à nossa decodificaçāo, própria e contemporânea, cinqüenta anos após a sua formulação, cem anos após o seu longínquo ponto de fuga na experiência infantil de um autor (5). Conforme a teoria de Benjamin, teríamosque levar em conta, diante de cada uma das imagens, a sempre repetida polarizaçäo, em refraçöes sempre renovadas de, por um lado, componentes sociais e críticos da ideologia e, pelo outro, componentes utópicos ou mesmo pré-históricos. Com isso, corresponderíamos à proposta benjaminiana da dialética da história cultural, de que de cada situaçāo negativa pode ser ganho algo de positivo, através de um processo infinito de divisão - e isto, em princípio, "até que todo o passado, através de um processo de apocatástase histórica, tenha sido introduzido no presente" (6). Falaremos a respeito disso durante o nosso simpósio. Masagora deixo este tema de lado, para retomá-lo logo mais, por outros caminhos.

Enquanto herdeiros de Benjamin, temos de ser mais ricos do que ele próprio, porque a sua obra nos veio de presente e principiou a desfraldar suas forças modificadoras no tempo, modificando-se a si própria ao mesmo tempo. Nẫo sei se eu, enquanto especialista na época barroca, ou seja, bastante afastado dos acontecimentos atuais, estou apto a formular o que se segue, mas não posso dizê-lo de outra forma. Este fenômenoé um dos mistérios da fisiognomia cultural da segunda metade de nosso século que mais desperta surpresa e mais provoca reflexão. Quando Benjamin morreu, nenhum dos seus cinco livros estava em circulação, nem era objeto de debate. Não tenho a impressão de que sua Dissertaçāo tenha tido um papel importante na pesquisa do Romantismo, que já na década de 20 estava a fortificar os seus bastiōes nacionalistas e racistas. A respeito do seu livro sobre o Barroco, sabemos que, com exceção de Günther Müllers, nenhum dos representantes da nova tendência, em pleno florescimento desde a década de 20 , falou a seu respeito. As traduçōes de Baudelaire, diante das quais Benjamin colocara um escudo protetor, como diante da obra sobre o drama barroco alemão, pela própria natureza do caso atingiram, na sua preciosa edição limitada, um circulo muito restrito. E Deutsche Menschen só se infiltrou no Reich por canais subversivos. EinbahnstraBe (Via de Mão Única), num país sem tradição jornalística de crítica social ou aforística, só podia ser um acontecimento para connaisseurs. Não. No tempo da República de Weimar, Benjamin era conhecido e respeitado como crítico, mas esta produçăo, nāo obstante a profundidade nela contida, justamente por ter sido veiculada através de jornal ou revista ou rádio, estava fadada ao esquecimento $\mathrm{e}$ à caducidade $\mathrm{e}$ nāo à tradição e à durabilidade. Benjamin tentou reagir, na medida de suas forças, contra a precariedade da maior parte de sua produçâo a partir de meados da década de 20 , na medida em que passou a arquivar meticulosamente tudo o que era impresso e também o que não o era, e a fazer as correçōes mais conscientes possíveis de todas as tergiversaçōes e falsi- 
ficaçöes de seus escritos, enviando os resultados deste esforço aos meus amigos, para uma distribuição a mais ampla possível. Mesmo assim, quando ele recorreu ao último meio ao seu alcance, ao alcance de seu livre-arbítrio, ao suicídio, Benjamin sabia que nẩo havia realizado a maioria de seus grandes projetos e que aquilo que, no fim das contas, ele havia conseguido terminar sob as circunstâncias mais adversas, estava sendo abandonado ao mais incerto dos destinos. A obra sobre as galerias, os ensaios sobre a literatura, o livro sobre o haxixe, sobre os quais ele já falara no ano de seu planejado suicídio como de um "monte de escombros ou local de uma catástrofe", não estavam encerrados. A Infância Berlinense ficara em estágio de manuscrito datilografado. Nãosei de nenhuma outra obra de autor do século XX - mas podem-me corrigir se eu estiver errado - em que haja uma tal defasagem entre a sua publicaçāo em vida e divulgaçăo póstuma. No caso do Homem sem Qualidades de Musil - talvez, pela sua dimensão, a obra mais facilmente comparável com a de Benjamin sobre as galerias - já haviam sido publicados dois volumes $\mathrm{em}$ vida do autor e o terceiro apareceu como fragmento um ano após sua morte. A obra de Hoffmannsthal, não obstante a imensa riqueza do que nāo foi publicado em vida do autor, havia sido dada a conhecer em suas manifestaçōes mais marcantes antes de sua morte. Talvez no caso da grande afinidade eletiva de Benjamin, no caso de Kafka - mas não tenho bem certeza - possa ser encontrada uma desproporçāo comparável entre publicação e grau de conhecimento em vida e bibliografia e fama universal póstumas. Seja como for, atenhamo-nos a Benjamin. Não considero que me tenha sido proposta a tarefa de repetir, diante deste público, as etapas da recepçāo da obra de Benjamin, que já enumerei há quatro anos (7). E também nāo quero e năo posso fazer aqui a complementaçăo deste estudoaté 1990 . Em lugar disso, quero que nos perguntemos juntos a respeitodos motivos internos à obra, responsáveis por esta recepçāo, a mais surpreendente e vivaz do nosso século, comoo editor Unseld proclamou com razāo e nāo apenas com finalidades publicitárias. Gostaria de enumerar as seguintes cinco características:

1. A universalidade da temática. Benjamin ocupou, desde a juventude, todas as disciplinas clássicas da filosofia. Podemos verificar isso nas suas obras reunidas $\mathrm{e}$, da melhor forma possível, no sexto volume, que já junta os fragmentos a partir da ordenaçấo temática. Filosofia da linguagem e crítica epistemológica, moral e antropologia, filosofia da história, historiografia e política, estética, crítica literária e áreas limítrofes, assim se denominam as divisöes, sendo que a última precisaria ainda ser diferenciada em grafologia, etnografia e arte popular, telepatia, teoria dos jogos, astrologia. Todo conhecedor de Benjamin sabe que esta lista nāo está esgotada. Poderíamos acrescentar ainda, com facilidade, a teoria da mídia (fotografia, cinema e rádio), a mitologia, a psicologia, a arqueologia, para nāo falarmos nas áreas do contexto da obra sobre as galerias.

2. Esta gama tão ampla de temas está protegida doecletismo do diletante, em primeira instância pelo fato de que em nenhuma das rubricas deixou de ser respeitado o estado atual da pesquisa. Antes pelo contrário, parte-se dele para produzir um desenvolvimento ulterior definível com precisão. Este desenvolvimento ocorre, porém, freqüentemente, através da combinaçăo de disciplinas, de seus questionamentos $\mathrm{e}$ tentativas de soluçāo, que nunca antes haviam sido justapostos da forma como Benjamin o faz. Benjamin não respeita a delimitaçāo nem o isolamento de áreas e disciplinas não apenas na crítica da arte em si, mas também em seus modelos originais de reflexảo, e chega, assim, graças a esta surpreendente contaminaçāo, a novas descobertas.

3. Observou-se com frequiência e salientou-se desde cedo, justamente por Adorno, que Benjamin desenvolve a sua filosofia - se me for permitida esta abreviação e ela nāo tiver de ser explicada novamente - na exegese de textos existentes. Isso the valeu repetidamente a acusaçăo de forçar os textos de suas fontes e de incorrer num crasso subjetivismo. Uma acusação que, se for justa, acho eu, seria mortal e condenaria todos os esforços de Benjamin. Penso que o procedimento empregado por Benjamin é, ao contrário, a conseqüência de uma teoria da imagem dialética e de uma teoria, correlacionada com esta, a respeito da sobrevida de fenômenos culturais, a respeito da qual já dei alguns indícios pouco acima, e que terei de retomar e explicitar logo mais. Esta forma própria a Benjamin de comentaros grandes textos, ativandosimultaneamente o acervo integral de suas idéias mais originais, tem como conseqüência, do

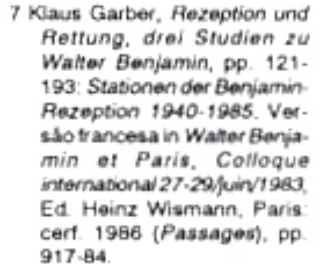


poṇto de vista da história da recepção, o fato de que a filologia de incontáveis autores da história literária alemã e francesa tem que digladiar sempre e ao mesmo tempo com estas duas partes: com os autores em questảo eles próprios e com a sua apropriação $\mathrm{e}$ interpretaçâo por Benjamin. Isto fica imediatamente evidente nos casos de Baudelaire, Kafka, Proust e Kraus, parcialmente também no de Brecht.

4. Não conheço nenhum escritor do século XX que dispusesse de um repertório tão amplo de formas literárias como Benjamin. Aqui, diante de um público de connaisseurs, nāoprecisoespecificare posso mencionar apenas, $\mathrm{sem}$ pretensöes a ser completo, o tratado monográfico, o ensaio, o comentário, o aforismo, o fragmento, a crítica, a resenha, a montagem, a peça radiofônica e o modelo acústico, a narrativa radiofônica e o ensaio radiofônico, o relato de sonhos e dos efeitos de drogas, o conto e a novela, o relato de viagem e a descrição de cidades, a imagem de pensamentos, o poema, sobretudo no formato do soneto, o diálogo, a entrevista, o relatório, a crônica, a anotação autobiográfica e, last but not least, naturalmente também a traduçāo e a carta. Para os fins da recepção da obra de Benjamin parece-me ser decisiva a afirmaçäo de que todas estas formas sāo empregadas de modo justo, que corresponde seja às suas leis formais existentes, seja às que Benjamin especificamente desenvolveu - e que, ao mesmo tempo, todas se constituem em meios do contínuo do pensamento e da experiênciabenjaminiana. Istoquer dizer que, neste sentido, Benjamin satisfez incomensuravelmente para o século XX, na obra de sua vida, a dialética desenvolvida $\mathrm{cm}$ seu livro sobre o Romantismo, que fala da especificaçäo e diferenciação formal, $\mathrm{cm}$ permanente progresso, dos conteúdos artísticos e de sua simultânea retrataçâo $\mathrm{e}$ abrogação neste único meio da arte. Conseqüentemente, para a recepção, que é oúnico ponto que estamos discutindo agora, toda nova ruptura da reflexão, descoberta num determinadotipode forma, obriga a um novo mergulho no todo do corpus restante de sua obra, acrescentando-lhe, com certeza absoluta, uma nova nuance. Todo leitor e pesquisador de Benjamin conhece este processo de movimento incontido entre os gêneros, entre o maior c o menor.

5. Em quinto e último lugar, algo que também é sobejamente conhecido. Benjamin, em sua teoria da representação, desen- volveu a recepçāo como sendo não apenas uma reconstituiçảo do pensamento, mas também como sendo uma ponte reflexiva por sobre o abismo que necessariamente resta na escrita, entre uma frase e a seguinte, como lei formal implícita a toda manifestaçāo feita através da linguagem. $\mathrm{O}$ que ele tinha a dizer não era apenas passivel de ser dito de forma mais simples, mas também, produçâo da lei inerente à representaçâo, no decurso da própria representaçâo. Nela, segundo o discurso de Benjamin, os extremos não são balanceados num conceito que nivela as diferenças, mas são circunscritos como pólos de uma totalidade dialética. Portanto, toda tentativa de esconder, de mascarar esta dialética - cuja manifestação mais conhecida e controvertida é a da teologia messiânica e do materialismo histórico - e de dissolvê-la a favor de algum dos pólos, desvia-se necessariamente e a priori da lei formal da produção benjaminiana. Para acrescentar, ainda, uma última observação, diria que faz parte desta produção a absoluta igualdade de direitos do discursodiscursivo e do discurso icônico. A conseqüência desta equiparaçăo, do ponto de vista da história da recepção, é que o conteúdo de experiência histórica submerso nas imagens só se desenvolve na vida destas imagens - ou seja, após o que vimos, apenas se desenvolve na medida em que impregna integralmente a obra toda, com a qual ela se transforma permanentemente.

A partir de nossa situação, enquanto herdeiros da obra de Benjamin e em vista dela; ou seja, em vista da atualidade presente da obra de Benjamin, atrevemo-nos a agir. A minha pergunta, neste contexto, é a seguinte: Será que ela poderá ser novamente atualizada de forma eficaz, como o foi no final dos anos $60 \mathrm{e}$ início da década de 70 ? Será que algo assim é desejável? Será que aquela fase nāo foi justamente um descaminho? O que podemos esperar desta obra hoje e no futuro próximo? Acho que estas questōes seriam exigidas do historiador da recepçāo, após o passeio feito até pelo menos meados do anos 80 . A obra benjaminiana atingiu o seu auge, na Alemanha, na virada dos anos 60 para os anos 70 . A sua recepção havia sido preparada pela edição, assim como pela filosofia de Adorno, e estava sendo provocada simultaneamente, em medida crescente, pelas mesmas. Aomesmo tempo, e de forma cada vez mais nítida, Benjamin era entendido como corre- 
tivoda teoria onipotente da Escola de Frankfurt, era entendido como o materialista histórico maiscoerente, comooadvogadomais confiável das massas oprimidas, como a testemunha mais digna de crédito da açẫo revolucionária. Os fundamentos dessa recepçāo praticamente desapareceram como descalabro da esquerda, com o descalabro dos sistemas socialistas, com a suspeita total de idcologizaçāo que entrementes se associa com o conceito do socialismo. Scrá que o âmbito da influência de Benjamin está sendo reduzido para aquele que já lhe era próprio a partir dos anos 60 , o de um pesquisador $\mathrm{e}$ mestre estimulante, que indica alternativas e se afasta do ramerrảo acadêmico habitual, cuja influência é verificável de forma amiúde mais do que apócrifa nos inúmeros trabalhos dos cientistas mais jovens, que estâo começando a ter sua vez nos dias de hoje? Mesmo se nấo passasse disso, nāo seria pouco, e, em vista da tendência preocupante de acompanhar sempre o último grito da moda, seria um corretivo salutar, justamente na área das ciências da cultura. Mas se fosse apenas isso, seria, na melhor das hipóteses, apenas meio Benjamin e, com isso, iria fundamentalmente de encontro à sua obra, que tem como meta impregnar a totalidade dos campos vitais. Ora, sabemos, desde as primeiras intervençōes de Adorno, que a divisăo $\mathrm{em}$ zonas centrais e periféricas levaria a uma visāo inteiramente superficial da obra de Benjamin. Contudo, se nos perguntarmos a respeitoda atualidade de sua obra - $e$, na minha opiniāo, é esta a questão central do nosso simpósio - não há quem, individualmente, possa dominar toda a amplidảo dos âmbitos aos quais ela se estende. Acho, também, que isso não é necessário. Se, na obra de Benjamin, houver uma disciplina que assuma virtualmente a função de cobrir um espectro integral, esta é, aos meus olhos, a filosofia da história. Mesmo a filosofia da linguagem, concebida de forma igualmente universal, converge, se eu estiver certo, para a filosofia da história, pelo menos no que se refere à categoria da Revelação, a qual, como Scholem já verificara, em contraposição à categoria da Salvação, desaparece da obra tardia, mas nem por isso precisa ser apagada do pensamento. Seja como for, parece-me evidente que é sobretudo a filosofia da história de Benjamin que deverá ser reativada criticamente, hoje em dia, e deverá ser aplicada como corretivo salutar no debate em torno da fisiognomia

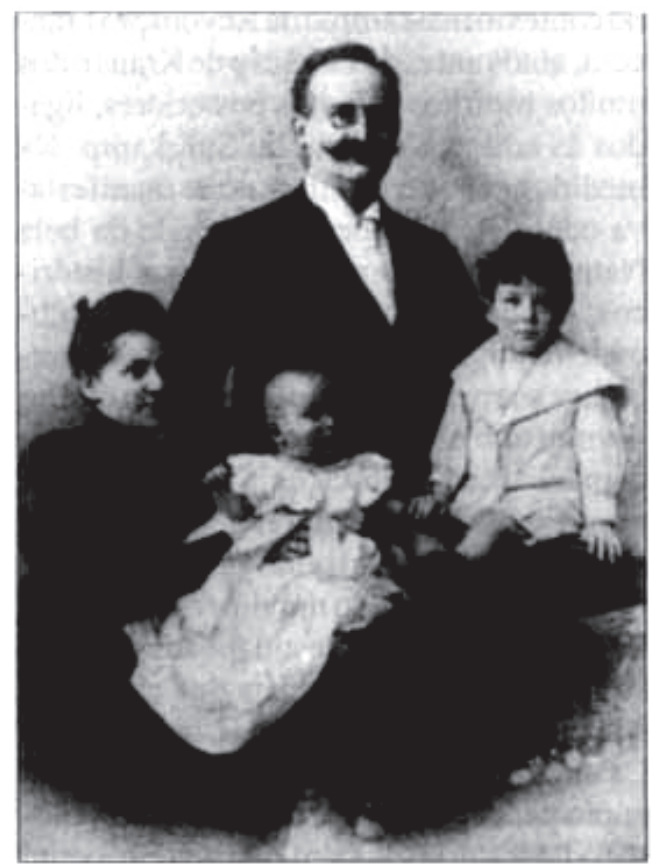

da modernidade e da pós-modernidade e na avaliação de ambas. Em seu centro, e não preciso me alongar aqui a respeito deste ponto, está o conceito de catástrofe. É minha convicçāo inabalável que Benjamin concebeu e escreveu o livro sobre o drama barroco alemão nāo só para resgatar a alcgoria e a melancolia, mas também porque se sentiu, desde o início, atraído pela imagem da história como palco das catástrofes, tal como aparece no drama barroco alemão. Também o fez à busca da cocrência expressiva - expressāo que ele ainda nảo usava entre o conceito barroco da história, a melancolia e a alegoria. Do ponto de vista da filosofia da história, portanto, a modernidade se inicia sob o signo do luteranismo, que desvaloriza a realidade, assim como culmina sob o signo do mundo das mercadorias, no auge do capitalismo, em meados do século XIX, motivo pelo qual o livro sobre Baudelaire teria constituído o complemento exato do livro sobre o barroco, se Adorno nāo tivesse achado que seria mais esperto que seu mestre e, em vez de se concentrar na intervençāo e na proibição, tivesse ficado restrito à espera paciente pelo amadurecimento, noque se refere à publicaçấo da obra benjaminiana. Conseqüentemente, quando Benjamin se debruça sobre as tradiçöes iluministas existentes entre o barroco e Baudelaire, isto nâo pode se dar a não ser de maneira crítica. Nâo preciso recapitular, aqui, as muitas açöes de Benjamin em prol do resgate de restos de iluminismo perdidos
EMIL E PAULINE WALTERE GEORC 
nocontexto mais amploda Revolução Francesa, ainda antes de Lukács e de Kraus e dos muitos espíritos solícitos posteriores, ligados às editoras Aufbau ou Suhrkamp. Na medida em que o Iluminismo se manifestava confiante na indestrutibilidade da bela Natureza até mesmo nos campos históri$\cos$, públicos ou morais, Benjamin o submeteu a julgamento, sobretudo em seus trabalhos sobre Goethe. Na medida em que no Iluminismo a idéia de progresso estava fundamentada na história (cuja função outrora progressista the era naturalmente familiar), Benjamin a pinçou junto aos sucessores iluministas, dentro do movimentooperário, movido por motivos de atualidade política. A última traiçāo desta idéia que ele veio a conhecer foi o pacto entre Hitler e Stálin. Bastava apenas mais um giro no caleidoscópio para aparar do ponto de vista da filosofia da história também este volteio, como é sabido que ocorreu na crítica do conceito de progresso e na imagem do cenário da catástrofe, que se apresenta diante do anjo da história, nas Teses de Filosofia da História. A repetida menção de Benjamin da apropriação da técnica, necessariamente falida por causa da ordem social errada, a sua mençāo da imagem necessariamente errada da segunda natureza, tem, em princípio, condiçōes de abarcar ainda, pelo menos nos seus pontos de partida, opensamento desenvolvido, por exemplo, na teoria de sistemas ou na teoria da sociedade ou da história de Foucault a respeito do funcionamento independente do sujeito, quase automático e quase autônomo de sistemas parciais da sociedade, os quais nāo são passíveis de serem formulados ou dirigidos eficazmente por nenhuma força social. A esperança iluminista na razäo dentro da história, na vitória final do bom senso, mesmo que por trás das costas dos sujeitos, nāo teve Benjamin como advogado. Acho que também isso explica uma parte de sua virulência no pós-estruturalismo e quejandos, um tema a respeito do qual seria indispensável fazer um trabalho abrangente, do qual eu, infelizmente, nāo sou capaz (8).

A única pergunta que sou capaz de formular e que, aos meus olhos, tem atualidade no marco da história de sua recepção, diz respeito aos elementos do pensamento histórico benjaminiano, se conseguem se afirmar frente à grassante renúncia à história, mais precisamente frente à renúncia à esperança de outrora em que os homens, enquanto seres responsáveis por si mesmos, estariam em condiçōes de marcá-la, de se auto-afirmarem, sem cair pura e simplesmente sob suspeita de ilusionismo, ingenuidade ou utopismo. A resposta a esta pergunta obriga o expositor a se expor - inevitavelmente. Éminha opiniāoque Benjamin achava que o socialismo ou o comunismo, em suas formas existentes, não tinham a menor chance, e que viu confirmada esta convicçāo pelo pacto entre Hitler e Stálin, um passo que nẫo podia ser justificado por nenhuma elucubração tática e que deveria levar, forçosamente, a uma desmoralizaçāo da esquerda. Eu digo que Benjamin nāo concedia mais nenhuma justificativa histórica ao comunismo soviético e seus derivados, após os processos viciados $\mathbf{e}$ as liquidaçōes em massa, porque o movimento socialista havia aberto mâo, sem necessidade e com imensos prejuízos, das suas raízes teológicas, que lhe tinham vindo através do Romantismo e do socialismo utópico e também lhe eram próprias, perdendo, com isso, um aliado, cuja perda o desorientou e o entregou, indefeso, aos mecanismos imanentes ao poder. Neste sentido, a primeira tese de filosofia da história nâo pode ser vista apenas de forma metafórica. Naturalmente, a necessidade de provar esta tese é grande, pois, em verdade, não se trata de falar o mesmo discurso dos agrupamentos eclesiais e religiosos afirmativos. Contudo, a tentaçāo de - peço desculpas - analisar a Teologia da Libertação em solo latino-americano, à luz do pensamento de Benjamin, esta tentação é realmente grande. Permitam-me dois lembretes, através de duas citaçōes.

No primeiro escrito de Benjamin, decididamente crítico das condiçôes sociais, na Via de Mão Única, já se pode ler a frase:

"Parece vir até nós, dos costumes mais antigos dos povos, como uma advertência, de que devemos cuidar de nāo cometer o gesto da cobiça ao aceitarmos tudo aquilo que recebemos com tal riqueza da Natureza. Porque não temos a capacidade de dar algo de próprio à Mãe Terra. Por isso é de bom alvitre mostrarmos respeito ao recebermos, devolvendo a ela uma parte de tudo aquilo que desde sempre recebemos, antes de apossarmo-nos do que é nosso" (9).

Correspondendo a este trecho, encontramos no último escrito de Benjamin um trecho que rejeita a fala míope e tola de Von 
Dietzgen, de que a Natureza, no fim das contas, está grátis, à nossa disposiçāo:

"Segundo Fourier, otrabalhosocial bem estruturado deveria ter como conseqüência que quatro luas alumiassem a noite terrena, que o gelo se afastasse dos pólos, que a água do mar perdesse seu sabor salobre e que os animais ferozes se pusessem a serviço dos homens. Tudo isso ilustra um trabalho que, longe de explorar a Natureza, é capaz de fazê-la dar à luz as criaçốes que dormitam em seu seio como possibilidades" (10).

São citaçōes usadas com freqüência, sei disso, e por isso fazem cair sobre mim a suspeita de abusar da hospitalidade desta casa com um discurso eleitoreiro do Partido Verde. Nada disso. O que me interessa é apenas tentar concretizar um pouco a imagem do boneco da teologia, aliado ao qual o materialismo histórico poderia topar qualquer parada. Isto, repito, sempre em vista do pessimismo pós-moderno frente à história, para cuja justificaçāo, de fato, não precisamos citar quaisquer exemplos. No fundo, Benjamin ficou fiel à idéia marxista da préhistória, do ingresso ainda nāo acontecido na história da humanidade, na medida em que a prolongava até o seu próprio presente, impedindo, assim, que a esquerda deitasse qualquer espécie de olhar satisfeito sobre o já atingido. E ele aliava o progresso no sentido legítimo, não no sentido depravado, a uma visão genuinamente marxista de um processo de troca bem-sucedido entre homem e Natureza, de humanizaçāo da Natureza e de naturalizaçảo do homem, no sentido dos manuscritos de Paris. Não pode haver qualquer dúvida séria a respeito de que, na passagem sobre Fourier, datada do último ano de vida, ainda ressoa a libertação da Natureza de sua mudez, no ato adâmico da nomeação das coisas; de que aqui entra no campo visual um conceito de trabalho que seria capaz de não sabotar a priori, através da submissão, aquilo que Benjamin visava com a experiência da aura. $\mathrm{O}$ mundo natural continua a depender da traduçāo, continua a depender da intervençāo auxiliadora do homem, continua a depender de alguém que ajude a dar à luz as forças que nele dormitam. Este pensamento protoromântico, que fascinava Benjamin desde a juventude, através da tradição messiânica e da doutrina das línguas naturais, este pensamento indelével na história do socialismo utópico, sofreu no seu pensamento teológico-materialista tardio uma nova reformulação, cuja atualidade é bem evidente.

Inversamente, ou melhor, de forma complementar, o crítico da violência estava suficientemente vacinado contra qualquer sancionamento da violência estatal ou social, mesmoda revolucionária. Evidentemente, a politizaçāo que Benjamin procurava estender ao campo totalmente negligenciado da estética incluía a educaçâo para a violência contra o fascismo, dentro da Frente Popular. A teoria benjaminiana nada oferece para a eliminaçāo dos assim chamados desviacionistas de extrema esquerda ou de extrema direita, para a deformação stalinista da revoluçâo. E nem poderia, porque o mandamento do respeito abarca o ser humano. Analogamente aos anos 30 , estão vindoà luz do dia crimes cometidos em nome do socialismoou do comunismoem Tartyn, Bucareste ou Berlim. Todos eles são culpa da absolutização da política, combatida por Benjamin até oúltimo instante, contra a qual ele se insurgia, em nome do iluminismo profano. Todos conhecemos a resposta de Benjamin à frase de Horkheimer, de que "as injustiças passadas são passadas e encerradas. Os trucidados estão realmente trucidados... Se levarmos o nâo-encerramento realmente a sério, será necessário acreditarmos no Juízo Final..." Benjamin, a isso: "O corretivo para tais pensamentos está na reflexão de que a história não é apenas uma ciência, mas é também, em grau não menor, uma forma de relembrança" (11). "Aquilo que foi 'verificado' pela ciência, pode ser modificado pela relembrança. A relembrança pode transformar o não-encerrado (a felicidade) em encerrado e o encerrado (o sofrimento) em năo-encerrado. Isto é teologia; mas na relembrança passamos por uma experiência que nos proíbe entender a história de forma fundamentalmente a-teológica, da mesma forma que nós não devemos tentar escrevê-la em termos imediatamente teológicos" (12). O que Benjamin queria era quebrar o que já estava encerrado. Deveria ser dada voz aos vencidos, aos violentados, aos emudecidos. A construção de Benjamin nos é, entrementes, tão sobejamente conhecida, que corre o riscode não mais poder transmitir seu tremendo apelo. Só o historiador terá o poder de ouvir esta voz do passado, que, no presente, fica do lado daqueles que estāo na sombra. A imagem dialética, a imobilizaçăo da histó-
10 GS, 12,699

11 Ou de "contra-memoria", para empregar a expressio de Norbert Bolz. (N.T.)

12 GS, V/1, 589. 


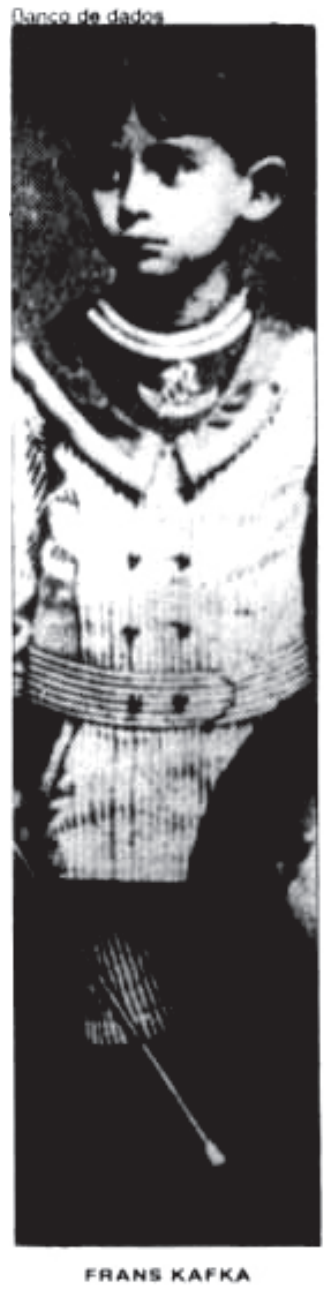

ria, realiza-se apenas e fundamentalmente através dos vencidos, enquanto a garantia da continuidade histórica é reservada à parte dominante contrária. Este lugar, do lado certo, espera pelo historiador a toda hora $\mathrm{c}$ em toda situação, mesmo aquela que parece não ter saída. Ele pode ser avistado sempre. Permitam-me mais uma incursão na história latino-americana contemporânca. Os arrogantes restos da esquerda, cheios de auto-comiseração, puderam obter nos últimos meses, junto aos movimentos de direitos civis da RDA, surpreendentes aulas de recuperaçāo. Bārbel Boley respondia à freqüente pergunta a respeito de como os iniciadores da democratização da RDA suportariam ver a sua supressão e integração no paraíso ocidental, dizendo que isso significaria a volta ao estágio em que se estivera antes, e durante anos. Ao estágio de uma minoria submetida a todos os perigos, sempre abalroada, mas nem por isso resignada nem desistente. Mais de um dos seus rostos, marcados pelosofrimento, mas nem por isso inconsoláveis, pôde voltar a transmitir, pela primeira vez, esta aura ao telespectador alemāo ocidental, realmente pouco habituado a tais imagens. Por favor, nada de glorificar os humilhados e ofendidos. Mas a relembrança à maneira de Benjamin se dá a partir do perigo. Nela, tornar audiveis as palavras proféticas e os atos dos mortos vencidos e a permanência junto aos ameaçados de hoje sâouma e a mesma coisa. Nos esboços do texto sobre as galerias, destinado ao instituto nova-iorquino, e em outras passagens, Benjamin fixou a natureza da imagem dialética como casamento de traços típicos do tempo presente e da história primitiva e precisou estes últimos como imagens sonhadas de uma sociedade sem classes. Adorno, enquanto hegeliano conseqüente, fez questäo do caráter mediado e portanto historicamente distinto também das imagens sonhadas, e Benjamin teve de concordar. Mesmo assim, ficou dominado pela idéia de que em qualquer presente a vida mais elevada e inconspurcada possivel seria acessível à experiência de cada indivíduo, e que nela ter-se-iam mantido promessas que outrora faziam parte dos templos didáticos dos teólogos, mas que também eram acessíveis às simples experiências de fé de cada indivíduo. Já dei alguns indícios neste sentido. Todo julgamento se detém, segundo Benjamin, diante da esfera moral, porque ela se refere exclusivamente ao lado que cada homem tem voltado para
Deus. Coerentemente, a sua filosofia da linguagem está permeada da idéia do impronunciável, do indizível, para o qual a linguagem apenas pode remeter de forma simbólica.

Lembrando o cinqüentenário da morte de Benjamin, vejo diante de mim, indeléveis, dois gestos nosquais surge aquiloque, para além da luta dos espíritos, também faz parte da presentificaçăo de Benjamin. Uma é a imagem daquele que foge, em companhia de um pequeno grupo, para o mundo dos montes Pirineus, marcado pelo esgotamento, mas mesmo assim abrindo máo do gole refrescante para o bem dos companheiros, para logomais, sem levar em conta a sua própria vida, jogar-se sobre um charco para beber impensadamente a água parada. E a outra é a imagem da sua própria morte, que foi compreendida pelos seus companheiros, os quais imediatamente puderam atravessar a fronteira, como um sacrificio, do qual um de seus amigos mais íntimos, Friedrich Podzus, voltou a falar em 1955. Neste mistério encerra-se a vida de Benjamin. Faz parte de sua obra em uma medida maior do que a que até agora soubemos desvendar. Nada seria mais injusto, para com Benjamin, do que subtraí-la do tempo. O que gostaria de ter deixado claro, nesta minha contribuiçāo, é que, até nova ordem, esta obra deve se tornar nosso bom companheiro, evidentemente incapaz de ser suplantado por quem quer que scja. Permaneçamos no campo da história, assim a herança da riqueza que nos coube parecerá ser tripla. Mesmo sob circunstâncias catastróficas, a obra da salvaçāo precisa ser inaugurada. Há potencial suficiente no passado. Necessita de atualizaçăo Correspondentemente, não se pode pensar qualquer presente a que nāo seja próprio um campo de ação, uma série de possibilidades de atuaçăo, que precisam ser reconhecidase percebidas. Nada nomundo, nem as catástrofes do passado, nem o horizonte obscurecido do presente, desculpam a acídia, o abatimento do coração enquanto resignaçâo, enquanto desespero diante da intervençảo sempre possível. Há brechas e nichos nos aparelhos, mínimos, porém desocupados, que é necessário conhecer e aproveitar, no sentido do início da via de māo única. $\mathrm{E} \mathrm{em}$ terceiro $\mathrm{c}$ último lugar: $\mathrm{o}$ potencial instituidor de sentido é restrito, mas está presente em todos os tempos, assim como pode ser descoberto $\mathrm{em}$ tudo que já passou. Ele é significado no discurso 
mascarador-desmascarador da lasca messiânica, do Messias, que pode penetrar a qualquer momento pela menor fenda. Levar a sério Benjamin significa ajudar a dar vida a este discurso, sempre.

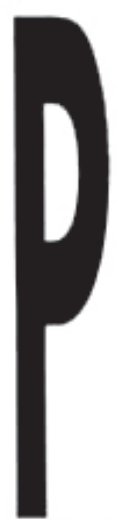

\section{WIIII BOI!E}

ara responder a essa pergunta, ć preciso examinar a validade do pressuposto. Se entendemos por "espólio" o "legado cultural", pode-se afirmar de fato que a recepçâo de Walter Benjamin no Brasil se constituiu numa contribuiçẩo notável para as ciências da cultura. Durante os anos 1970 e sobretudo os 80 foram traduzidos numerosos textos seus e publicadas sobre ele dezenas de estudos ou aplicaçōes de scus conceitos a outras obras (1). A questão da "riqueza" do espólio do "pobre W. B." suscita também a pergunta pelo contexto histórico-social de produçâo da obra. Assim, Benjamin tentou compreender a modernidade de Baudelaire - enquanto $\mathrm{ex}$ pressäo artística e crítica de uma "modernizaçāo" mal resolvida - diante do conflito entre ricos e pobres:

"Seja qual for o partido a que se pertença (...)é impossível nâoficar comovidocom oespetáculodessa multidâodoentia, que traga a poeira das fábricas, inspira particulas de algodāo, se deixa penetrar pelo alvaiade, pelo mercúrio e todos os tóxicos usados na fabricação de obras-primas...; essa multidāo se consome pelas maravilhas, as quais, não obstante, a Terra the deve. Ela sente correr $\mathrm{em}$ suas veias um sangue púrpura e lança um olhar demorado e cheio de tristeza sobre a luz do Sol e a sombra dos grandes parques..."(2)

O contraste aqui descrito entre a população miserável da periferia e o luxo e resplendor da "capital do século XIX" se reproduz em escala maior nas relações entre os países metropolitanos, os que dominam a economia mundial, e os periféricos. Nosso lugar de recepçâo de Benjamin - uma megalópole do Terceiro Mundo-é propício para trazer à tona um aspecto pouco observado até agora. O estudo sobre "A Paris do
Segundo Império em Baudelaire", que integra a "Obra das Passagens", desemboca na "Era dos Impérios", implicando um diagnóstico do imperialismo oitocentista (3). De uma leitura dos textos benjaminianos numa dimensāo comparada pode se esperar alguma elucidaçãosobre as relaçöes entre metrópole e periferia.

Para dar uma idéia do que se trata, vejamos esta imagem poética, comentada por Benjamin, do poema de Baudelaire L'Invitation au Voyage:

"Vois sur ces canaux

Dormir ces vaisseaux

Dont l'humeur est vagabonde;

C'est pour assouvir

Ton moindre désir

Qu'ils viennent du bout du monde" (4).

A imagem baudelairiana dos navios é vista pelo crítico como uma representação da Modernidade heróica. Complementando a figura do dandy, Baudelaire é mostrado em busca de imagens de desejo, "entregue ao espetáculo dos navios no cais" (5). Ora, os versos falam, discretamente, de um conteúdo factual histórico: a circulação das mercadorias no mercado mundial. Em vista disso, nāo seria mais plausível compreender o poema como encenação irônica de um papel - o do consumidor que, nas vitrines da Metrópole, como um príncipe, tem a seus pés a abundância das mercadorias de todos os países do mundo? (6) Essa atmosfera é apropriada a colocá-lo num estadode êxtase, a se embalar, numa sensaçāo elevada de ubiqüidade cosmocêntrica, em luxe, calme et volupté. Embriagadopeloeldorado das mercadorias, ele sonha, de maneira tāo ingênua quanto obcecada, os sonhos de dominação de um império.

As relaçōes entre metrópole c países dependentes, abordadas por Benjamin a partir de uma perspectiva européia, requerem como complemento uma elucidação através de um olhar em sentido inverso: da "periferia" em direção ao centro hegemônico. Oprisma de percepçãode uma das grandes cidades do Terceiro Mundo pode ser fundamental para "revelar" os retratos urbanos do autor:

"Le passé a laissé de lui-meme dans les textes littéraires des images comparables à celles que la lumière imprime sur une plaque sensible. Seul l'avenir possède des révélateurs assez
WILLI BOLLE professor de Literatura na USP e organizador do livro Documentos de Cultura - Documentos de Barbárie. Escritos Escolhidos de W. Benjamin (Cultrix) Edusp).
O lexto apresentaso no simpdeic foi inteiramente reeiaborado Este ensaio taz parte do fivro Fisiognomia da Metrópole Modema Represantacío da História am W. Benjamin, a ser publicado peia Edusp

1 A titulo de exemplo, enteo estudos mais fecentes. Roberto Schwarz, Um Mos. tre na Periferia do Capiealis. mo: Machado de Assis. Sto Paulo, Duas Cidades. 1950. A recepplo das ctras de Ben amin no Bras 4 chioto de uma tese de dourado are está sendo elaborada por Gunter Pressier (USP).

2 W. Benjamn, "De Moderne" in Gesammette Scrvition $1 / 2$ Frankturty, 1974, po. 576 . segs A otacho b do ensaio de Raudelaire ris, 1961, p. 610) sobre Pierre Dupont As traduçies de Ben. jamin sdo minhas, tendo con. sultado as já publicadas de Flávio Kothe (Ed. Ática) e José Carlos Martins Barbosa (Ed. Brasiliense)

$3 \mathrm{Ct}$. Eric Hobstawm, A Era dos impatios. 1875-1914, Rio de Janeiro, Paz - Torra, 1908

4 Charles Baudelairs, Onures Compldtes. Paris, 1951, D Sis

5 GS 1/2. p. 599

6. Poemas ent que se represer tam paptis (Rloflengedichted). caracteristicos por exemplo da lírica de Brocht, encon. tram-se tambem nas Fores do Mal O próprio Benjamin apentou para os dversos "pa. peis" de Baudelaire Raneur. apache, dandy, etc (GS I/2. D. 600 ) 
7 André Monglond, 1930, op of . GS V/2, DP. 603s e segs. (N15a, 1).

B Ao momento histótico de Tegbilidade" das imagens re. lere se tambern a seguinte passagern: "O indice histón. $c o$ das umagens náo diz ape. nas que elas pertencem a um determinado termpo, mas, 00 turetudo, que só se tornamle. tretuck, que so se tormam le. gives num determinadotem. po. Essa 'legibilidade' é um determinado ponto critico do seu movimento interior", GS V/1, pp. 577 e segs. (N3,1).

9 Neapel, GS IV/1, pp. 307-16

10 Sobre a representaçato da ci. dade na iteratura brasileira, dos inicios até o presente, v Elisabeth Lowe. The Ciry in Brazilian Literature. $198 \mathrm{~s}$

11 Ver Nicolau Sevcenko, tRic de Janeito y San Pablo: desarollo social y cultural com. parativo, 1900-1930\%, in Nuevas Perspectivas en los Estudios sobre Historia Urba na Latinoameticana, otgs Jorge E. Mardoy Pichard P.

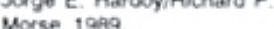

12 Mano de Andrade, "Paulicbia Desvairada", in Poesias Com pletas, 1987

$13 \mathrm{Cl}$. esta trase do Journal des Dutbats de 1831, ot por Ben. jamin: "Cada industrial vive ern jumin: "Cada industrial vive ern diários entre seus escravos" GS V/1, p. 58 .

140 duplo papel de Sło Paulo como cidade colonizada eco. lonizadora, explorada e exploradora toi reiterado recente. mente por Ivan Anjelo; v. sew. texto "Enigma", apresentado no Colóquio "Literatura de las Grandes Cludades". Berlim, 14 a 16 de junho de 1990.

15 Ver Wis Boile, A Cidade sem Nenhum Carater. Uma Leitu. ra da Paulicéia Desvaraicda de Mínio de Andrade Espaço Debates 27. 1989.

16 Como viajante entre a cidade de Baudelaire e a codade de Mário de Andrade, 0 antropólogo Claude Levi'Strauss for. nece um relato dessas tantasmagotias: et. Tristes Tropiques, 1955

17 Ver Antonio Candido, Ltera. fura e Subdesenvolvimento, 1970; Altredo Bosi, Celu e in. ferno. Ensaios de critica lite rária, 1988; Flávio W. Aguiat, Visóes do interno ou: O inter. no Somos Nós, 1988

180 seguinte comentánio rele. re-se a um episódio do cap XIII de Macunaima, intitulado "A piolhenta do Jigues". A im. portancia desse episódio para uma interpretaç bo culturat for Souza, O Tupi o Alatide Uma interpretaça de Macunaima, 1979, pp. 92.7

19 Situado na tace sul do Teatro Municipal, diante do monu. mentode Carlos Cicr mentode Canos Clcmes. com. positor da cpera O Guaran. texto embiemático do indranismo actifs pour fouiller parfaitement de tels clichés. Mainte page de Marivaux ou de Rousseau enferme un sens mystérieux, que les premiers lecteurs ne pouvaient pleinement déchiffrer" (7).

Com essa observaçāo de André Monglond, Benjamin aponta para um difcrencial de tempo, que faz com que certos textos "advinhatórios" só se tornem "legíveis" numa época posterior (8). A isso sc acrescenta um diferencial de espaço. O que faz a "legibilidade das imagens"? Na época $\mathrm{cm}$ que Benjamin redigiu seus retratos de cidades, as megalópoles do Terceiro Mundo ainda não existiam. Diante das diferenças históricas e geográficas entre os dois mundos, como extrair de seus retratos de cidades um modelo também válido para a representaçâo de uma metrópole sul-americana? É que determinadas estruturas de nossas grandes cidades foram antecipadas, de modo visionário, pelo autor daquelas "radiografias" da Modernidade. O primeiro dos quadros urbanos de Benjamin, o ensaio "Nápoles", escrito em $1924 \mathrm{~cm}$ coautoria com Asja Lacis, aponta significativamente em direção ao Sul (9). Aquela imagem apenas esboçada de caos, miséria c crime - a história se encarregou de completá-la em forma de uma ampliação gigantesca: a partir de meados do século $\mathrm{XX}$, um processo de crescimento explosivo, na Ásia, América Latina e África, fez surgir as maiores e mais problemáticas aglomeraçōes da história da humanidade. $\mathrm{O}$ discurso da Modernidade ficou de pontacabeça e os desdobramentos futuros são incalculáveis.

Para uma compreensão adequada das metrópoles do Terceiro Mundo deve se consultar, evidentemente, seus auto-retratos. Nós nos limitaremos aqui ao caso do Brasil. Desde quando existe na literatura brasileira uma consciência urbana moderna? (10) A metrópole nasceu no Brasil no início do século XX em Sāo Paulo. Devido a suas vantagens geográficas, sua infra-estrutura e à imigração, a cidade se tornou o centro industrial e comercial do país, e mais: seu principal foco de inovação cultural e artística (11). A metrópole brasileira aparece pela primeira vez como protagonista literária no livro de poemas de Mário de Andrade, Paulicéia Desvairada (1922). Trata-se de uma visâoadivinhatória, em que o poeta detecta energias que iriam transformar a cidade naquilo que ela é hoje.
Entre Mário de Andrade como grande figura do Modernismo brasileiro e Walter Benjamin como um dos "clássicos" da Modernidade alemā, existem, apesar das diferenças, notáveis analogias. Suas datas de nascimento estâo próximas (Benjamin, 1892; Mário, 1893), como também as datas em que cada um se pôs a escrever sua obra capital: as primeiras notas de Benjamin sobre o Projeto das Passagens são de 1927; Mário de Andrade publicou o seu romancerapsódia Macunaíma em 1928. Assim como Benjamin nunca chegou a sair da Europa, também Mário nunca saiu do Brasil. Uma afinidade literária eletiva liga os dois autores a Baudelaire.

O que os Tableaux Parisiens de Baudelairesignificam para Paris, Paulicéia Desvairada é para São Paulo. Lembrando o poema baudelairiano Paysage, também o ciclo urbano de Mário se estrutura em torno de quatro poemas deste título: "Paisagem" n's. 1, 2, 3,4. São Paulo é introduzida como "comoção" na vida do pocta c como "galicismo a berrar nos desertos da América"; no poema final faz-se ouvir o "grito inglês" dos valores da bolsa no mercado mundial, que repercute em São Paulo, principal entreposto de café (12). Na representação andradina do ritmo de trabalho da cidade, as vozes dos senhores de plantaçōes c dos trabalhadores braçais, das quais em Benjamin só se tem uma breve referência (13), fazem-se ouvir com nitidez maior. A auto-imagem da metrópole brasileira, situada na periferia do mercado mundial, fundamenta-se, como mostra Mário, tanto no controle sobre as terras mais remotas do próprio país, quanto na dependência em relaçāoàs metrópoles de verdade(14). Afora isso, existem $\mathrm{cm}$ seus textos numerosos outros elementos para se desenvolver afinidades com Baudelaire e Benjamin: o topos da caducidade da metrópole moderna; o ceticismo diante da ideologia do progresso; o cosmopolitismo crítico; a ironia e o sarcasmo diante das fantasmagorias dominantes; a utilizaçāo de máscaras, sonhos, alucinaçōes, a fim de driblar a censura; a incorporaçâo de imagens da loucura...(15).

Assim como Baudelaire e Benjamin se debateram com as fantasmagorias da Modernidade nas metrópoles européias, Mário de Andrade viu em Sāo Pauloo lugar apropriado para estudar as fantasmagorias da Modernidade nos trópicos (16). Ele colocou oseu trabalho como poeta, romancista c crítico a serviço dessa causa. Em sua 
obra (como também na de Oswald de Andrade)encontra-se ocorrespondente tropical da benjaminiana "fisiognomia da metrópole moderna”. A imagem baudelairiana da caducidade da metrópole foi uma resposta à remodelagem destruidora da cidade de Paris pelo prefeito Haussmann; a retomada do topos por Benjamin baseou-se na premoniçāo de destruiçôes futuras pelo regime nazista; nos trópi$\cos$, a caducidade das grandes cidades vem se acentuando do Modernismo em diante. A literatura brasileira urbana em nossos dias - com ficcionistas como Loyola Brandāo, João Antonio, Ivan Ângelo, Rubem Fonseca e outros - mostra, como temas preponderantes, a pobreza, a miséria, a violência, a degradação humana, a ausência de esperança. Um elemento comum desses autores é uma consciência pessimista da história. Às esperanças de emancipaçāo política e social, tais como foram despertadas e fomentadas pelo Modernismo, se sobrepôs, na crítica e no ensaísmo dos anos 70 e 80 , um ceticismo crescente (17). A consciência de um processode modernizaçãoinacabado, para nāo dizer fracassado, marca grosso modo a passagem da Modernidade à "PósModernidade". Uma leitura comparada de textos da Modernidade brasileira e alemA no caso, Mário de Andrade e Berjamin pode tornar mais claro o conhecimentodessa mudança de época.

$\mathrm{O}$ projeto benjaminiano de uma historiografia da Modernidade enquanto montagem de imagens dialéticas, no sentido de um "despertar dos sonhos coletivos", pode ser ilustrado por uma passagem paradigmática do Macunaíma de Mário de Andrade; trata-se de uma imagem arcaica que vai ao encontro da representação benjaminiana da metrópole (18).

Macunaíma, o "herói sem nenhum caráter”, que veio da selva amazônica para a metrópole São Paulo, a fim de recuperar o talismā perdido e reencontrar sua sorte, faz um passeio de fim de semana no centro, no Anhangabaú. Este nome indígena, com o qual se designa o vale no meio da cidade, um córrego coberto por uma avenida, significa "espíritos maus"; ele estaria relacionado com enxames de mosquitos que, desde sempre, infestaram aquela várzea, tornando-a um local de doenças. De fato, Macunaíma está meio doente. Abatido e melancólico, depois de uma longa caminhada pela cidade, ele se senta no parapeito de uma fonte, nas imediaçōes do
Anhangabaú (19). Construída em forma de gruta, a fonte é o molde de uma visĩo que toma conta do he rói. Moldura barroca, que introduz uma perspectiva em profundidade. Pois a imagem nascida da gruta oscila entre a mais recente modernidade $\mathrm{e}$ os tempos arcaicos, quando se iniciou a construçäo da identidade brasileira.

Da profundeza do espaço surgem, sempre crescendo, os contornos de uma embarcaçāo: "uma vigilenga", "um gaiola", "um vaticano"! $\Lambda$ visāo do herói se comunica aos que estão em sua volta, atingindo seu clímax na imagem de um transatlântico moderno, iluminado, relampeando "todo de oiro e prata embandeirado e festeiro". Os tripulantes e os viajantes, "argentinos finíssimos" e "donas lindíssimas", acenam chamando Macunaima. "- Gente! adeus, gente! Vou pra Europa que é milhor!" Macunaíma está se despedindo de seus patrícios, pelo visto, para sempre. Ele conhece o interior do Brasil, com seus rios imensos, os barrancos e bancos de areia, os campos, capōes de mato e caatingas, as cidades, principalmente a

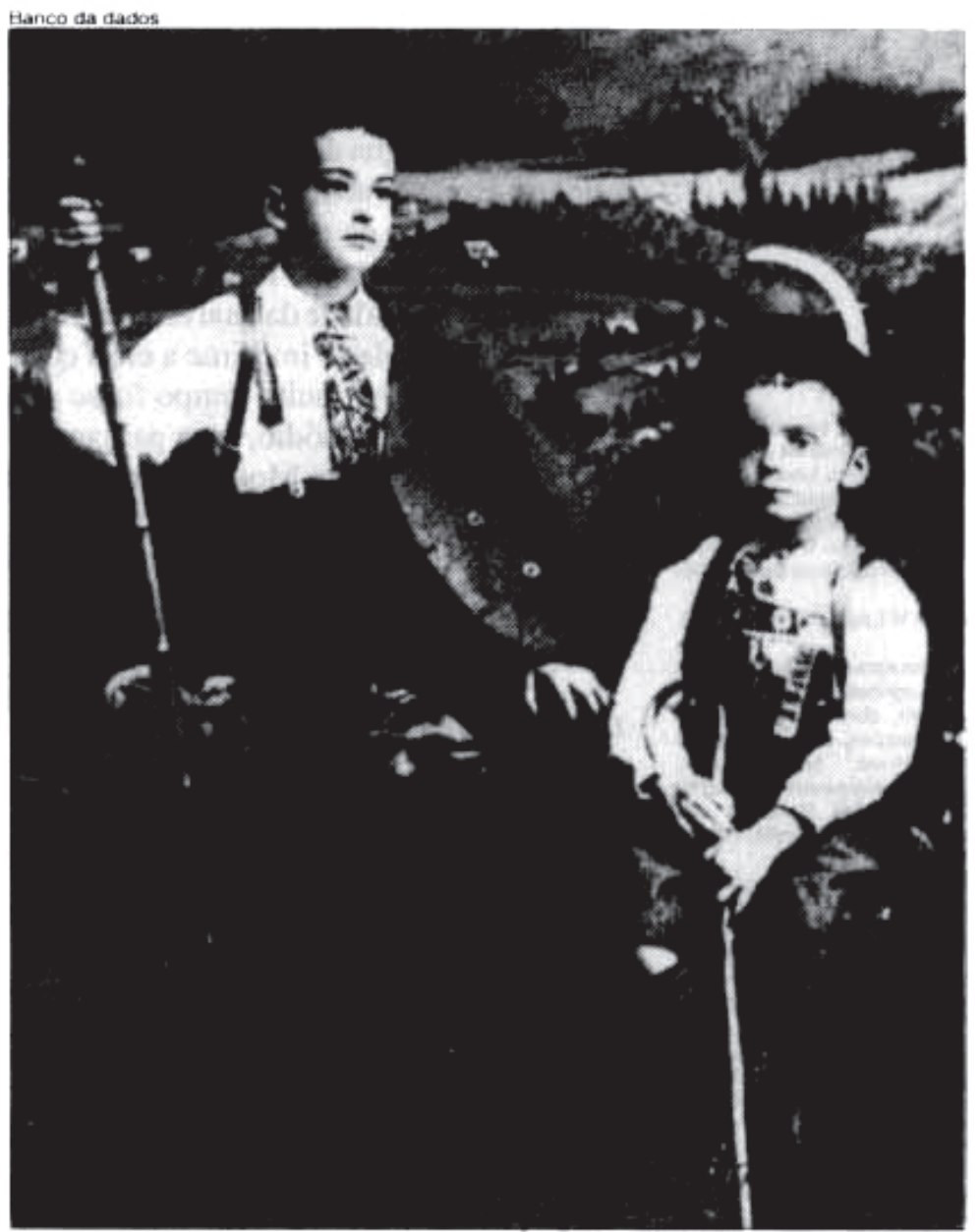


20 Gilda de Molio e Souza, p. 95.

21 A utopia do barroco europer quanto à Anerica é appesen. cada na obra Ner de Hental de Sergis Buara de Hotivos Edenicos no Descobrimento Colonizaçăo do Erasil, 1959

22 GS, V/1, pp, 515 e segs. (L2,6)

23 Uma apresentaçbo detainade do concento benjaminiano de mito, com suas diversas acepcos, encontra-se em Wintried Menninghaus. Schwellenkunde. Walte Benjamins Passago des Mythos, Franikturty, 1986

24 Erralung und Heilung, GS IV/ 1. p. 430 . Ver a interpretaçác de Jeanne-Marie Gagnebin.

25 Der Erzihier, GSII/2, po, 438 65. sobretudo P. 457 e segs.

26 Ver Heinz Schlatter. Denkbilder, Eine Kleine Prosatom mischen Dichtung und Gesellschaftstheorie. 1973

27 De Fant der Mascotte, GS IV/2, pp. $738-40$ maior e mais progressista e, apesar de tudo isso, quer ir para a Europa.

Esta imagem alegórica de Macunaíma é o contraponto à imagem dos navios da Invitation au Voyage de Baudelaire. Lá, um olhar europeu a partir de um cais europeu, aqui um olhar brasileiro, do lado de cá do Atlântico. Nesta alegoria de Mário de Andrade expressa-se "um tabu, um desejo recalcado" (20). Parece que a utopia européia de construir um "paraíso" nos trópicos fracassou - e de modo definitivo nos tempos modernos (21). Renegando a utopia barroca como fantasmagoria, Macunaíma sonha o sonho moderno (ou "pós"-moderno?) de uma volta para a Europa, onde se vive melhor que no Brasil. Os choferes japoneses ao seu redor e os marujos, que conhecem muitos cantos do mundo, incentivam Macunaíma em sua decisão. Ele pula "no cais da fonte", prestes a embarcar.

Neste momento, o transatlântico faz uma manobra, dando a popa para a terra. Os cavalheiros finíssimos, as garotas lindíssimas e os marujos, de lá de cima, recobrem Macunaíma de vaias e caçoadas, e a chaminé do navio cospe uma fumaçada de "pernilongos, borrachudos mosquitospólvora mutucas marimbondos cabas potós moscas-de-ura, todos esses mosquitos", que envolvem o herói, trazendo-o de volta para a realidade. A água da fonte volta a ser prosaica, mostrando ao herói a imagem de um homem coberto de picadas, erisipelado e febril. Decepcionado, Macunaíma volta para a pensāo; a cidade da qual ele quis fugir o tem de volta, ela se imprime a ele a cada passo, como se há muito tempo fosse seu alter ego. Neste episódio, uma passagemchave do discurso da Modernidade brasileira, Mário de Andrade desenha a imagem da sociedade brasileira e de sua metrópole como a de alguém que literalmente "ficou para trás".

Nas Passagens Parisienses de Benjamin, um caderno fala das relaçōes entre "casa onírica, museu e termais”; num dos fragmentos se lê:

"Pensar a passagem como um hall de termais. Deseja-se encontrar um mito de passagem com uma fonte lendária em seu centro, uma fonte no asfalto que nasce no centro íntimo de Paris. Mesmo as 'fontes de cerveja' derivam sua existência desse mito da fonte. $\mathrm{O}$ quanto a própria cura é um rito de passagem, uma vivência de transição, mostra-se viva- mente nos peristilos clássicos, onde os pacientes caminham por assim dizer em direçāo à sua cura” (22).

Uma tal "fonte no asfalto" existe na imagem evocada por Mário de Andrade. Retirando seu sonho de uma fonte situada no centro de Sāo Paulo, Macunaíma quer "caminhar em direçāo à sua cura". Ele quer se aconchegar dentro de uma imagem de desejo, fugindo-de_uma realidade sentida como profundamente insatisfatória. $A$ história vivida por esta figura alegórica é apresentada como um emaranhado inextricável c inescapável de privaçōes c violência como um destino mítico, tal como Benjamin oconceituou em sua obra inicial. Nesse conceito sombrio do mito repercutem as experiências históricas de uma "cultura"que se abateu sobre as pessoas como um estado permanente de guerra. Diante disso, o crítico procurou elaborar instrumentos com os quais se possa quebrar o poder compulsivo do mito (23).

O tema da força curativa, à qual se refere a citada passagem das fontes termais, $\hat{e}$ aprofundado na imagem de pensamento "narração e cura" (24). No ensaio "O Narrador", Benjamin fala da capacidade mimética e mágica, própria do narrar desde os tempos arcaicos e com um poder equivalente ao do mito (25). Suas consideraçöes valem também para o Macunaíma. Enquanto o herói vive sob a compulsāo do mito, o narrador, em outro nível, busca uma saida. A obra ficcional de Mário de Andrade é um mergulho dentro dos sonhos e traumas coletivos, tentanto romper as amarras de um mundocompulsório através da comicidade. O mesmo objetivo é perseguido por Benjamin num outro gênero e com outros meios: uma obra historiográfica construída como "tentativa" ou "ensaio" de "despertar". Acentuando ora seu lado crítico, de estudioso da literatura e da sociedade, ora o lado artístico-mimético, de ensaísta e escritor, Benjamin funde os dois tipos de conhecimento num gênero novo que é a imagem de pensamento (Denkbild) (26). Na representaçãoda história da própria época, o escritor e o narrador em Benjamin têm às vezes a primazia em relação ao crítico e ao cientista. Éoquese dá num de seus contos intitulado "A Viagem do Mascot" (27) - uma imagem de pensamento, que retoma o tema dos navios em Baudelaire e Mário de Andrade, estabelecendo a ligação entre o cais europeu e o sul-americano. 
É o relato de uma viagem fantástica da "metrópole" em direção à "periferia". Durante a Primeira Guerra Mundial, navios alemães, cargueiros de salitre, ficaram retidos no Chile; depois do fim das hostilidades, eram para ser trazidos de volta para a Alemanha. O problema consistia em como fazer chegar tripulaçōes alemās até lá. Ainda estava muito viva a lembrança da rebeliāo dos marujos de novembro de 1918 estopim da derrubada da monarquia $\mathrm{e}$ da tentativa de uma revoluçãosocialista. Apesar dessas dificuldades, consegue-se finalmente juntar uma tripulaçāo que embarca na qualidade de passageiros. Uma vez em alto mar, acontecem as coisas mais estranhas: estabelecem-se cassinos de bordo, um ringue de boxe, um teatro amador, dança entre cavalheiros, uma bolsa de valores, um mercado negro; surge até mesmo uma mulher - e tudo isso, sem a intervençāo do capitāo. A essas diversōes acrescenta-se uma extraordinária atividade política. Um rematado agitador engaja-se num trabalho cotidianode conscientizaçâo da massa, acabando por criar um ambiente altamente politizado. Forma-se um Conselho de Marinheiros, são eleitos uma Comissão Econômica, uma Patrulha de Controle, um Secretariado de Bordo, um Tribunal Político. "Ouviam-se vozes que queriam que esta expedição se tornasse o começo de uma vida nova num Mundo Novo (...)." Um Comitê de Ação planeja com todos os pormenores o golpe. Mas as coisas acontecem de modo diferente. Quarenta e oito horas antes do motim cuidadosamente preparado, o navio atraca no cais de Antofagasta, sem que nada tivesse acontecido.

"A Viagem do Mascot" pode ser lido como uma imagem alegórica da Modernidade alemã entre 1919e 1933, ano da fundaçãoe do afundamento da República de Weimar. Os acontecimentos nessa "magic city flutante" simbolizam o passatempo com distraçòes; o exercício da plena liberdade $\mathbf{e}$ a vivência das utopias se revelam a posteriori como ilusórios jogos de bordo, programados com antecedência por um antagonista oculto. Os que acreditam estar fazendo uma revoluçāo, pensando ir ao encontro de uma vida nova num mundo novo, embarcaram numa ilusāo. Na verdade, trata-se de uma nau de insensatos, carregada de mercadoria humana, cujo preço e espaço de açăo foram calculados de antemäo. O "rematado agitador" revela-se no final como um animador de jogos contrata- do pelos armadores. No Trabalho das Passagens, Benjamin fala de "maitres de plaisir da burguesia", referindo-se a autores do romance de folhetim (28); por extensăo, o termo designa os profissionais liberais que ganham a vida na área da cultura, das exposiçôes, da publicidade. Eles são os produtores de imagens de sua época, a camada produtora de cultura entre a classe dominante $\mathrm{e}$ os dominados, camada colocada por Benjamin no centro de suas reflexöes, para obter maior clareza sobre a situação histórica de sua própria classe ou estamento (29). A narrativa benjaminiana configura-se como uma paródia e autoparódia dos mitos e das utopias da geração que viveu a República de Weimar que tâo pouco tempo durou; $\mathrm{e}$ uma alegoria da transitoriedade e do tempo que escapou aos jogadores.

Navegando no espaço imaginário entre Alemanha e América do Sul, aquela "magic city flutante" é também uma alegoria dotrasladodos textos benjaminianos para as terras tropicais. Procuramos dar aqui uma amostra de como funciona a historiografia alegórica benjaminiana. A relaçāo "metrópole/ periferia" foi comentada através de uma montagem de três imagens poéticas. Três imagens de navios, que embalam a imaginação. Baudelaire evoca o horizonte de uma circulação das mercadorias no mercado mundial a partir da perspectiva onírica do consumidor europeu, numa refraçāo irônica. Mário de Andrade, em contraponto à idcologia oficial do Brasil como país de imigração e "país do futuro", flagra uma radiografia do inconsciente coletivo: o desejo de êxodo. Quanto ao conto de Benjamin, seu pano de fundo é uma Europa destruidora e autodestruidora, de onde ele procura uma saída. Não é por acaso que o crítico, numa imagem, se auto-retratou como

"um náufrago à deriva numa carcaça de navio (mas ele vê ainda uma chance) de dar um sinal para sua salvaçāo" (30).

Sem dúvida, ultrapassamos o limite da pergunta sobre oespóliode Benjamin e seus "ricos" herdeiros. Oque nos motivou a fazêlo foi a inquietude semeada pelos textos de Benjamin e os rumos de uma "pós"modernidade, em que os sinais de naufrágio, registrados pelo crítico na metrópole do século XIX e do início do XX, ao invés de diminuírem, se intensificaram, pelo menos parte do barco da humanidade mais próxima da periferia.

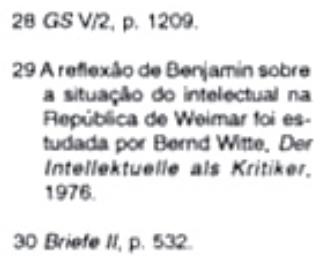
Pepuiblica de Weimar foi es. tudada por Bernd Wrte. Der Intellektuelle als Kritiker. 1976.

30 Briefe H. p. 532 